\title{
Bio-Banking on Neglected and Underutilized Plant Genetic Resources of Nigeria: Potential for Nutrient and Food Security
}

\author{
Catherine Veronica Nnamani', Happiness Ogba Oselebe ${ }^{2 *}$, Anastasia Ngozi Igboabuchi ${ }^{3}$ \\ ${ }^{1}$ Department of Applied Biology, Ebonyi State University, Abakaliki, Nigeria \\ ${ }^{2}$ Department of Crop Production \& Landscape Management, Ebonyi State University, Abakaliki, Nigeria \\ ${ }^{3}$ Department of Biology, Nwafor Orizu College of Education, Nsugbe, Nigeria \\ Email: ${ }^{\text {happinessoselebe@yahoo.com }}$
}

Received 11 December 2014; accepted 2 March 2015; published 4 March 2015

Copyright (C) 2015 by authors and Scientific Research Publishing Inc.

This work is licensed under the Creative Commons Attribution International License (CC BY).

http://creativecommons.org/licenses/by/4.0/

(c) (i) Open Access

\section{Abstract}

The poor quality of habitual diet and lack of dietary diversity in Sub-Sahara Africa are grossly contributing to deficiencies of micronutrients in the menu of poor rural and semi urban communities particularly in Nigeria, leading to the high incidence of hidden hunger. This has manifested in the high prevalence of non-communicable diseases such as stunted growth, goiter, blindness, kwashiorkor and marasmus. Five underutilized traditional leafy vegetables (TLVs) of southeast Nigeria were assessed by standard methods to determine their physiochemical and antioxidant values. These TLVs were Abelmoschus esculentus (L.) Monench (Okra), Ageratum conyzoides Linn (Goat weed), Acanthus montanus (Ness) T. Anders. (Leopard's tongue), Bombax buonopozense P. Beauv. (Kapok Tree) and Mucuna flagellipes (Devil bean). Results showed that the leaves of Bombax buonopozense and Abelmoschus esculentus contained appreciable amounts of protein, fat, fibre, carbohydrate and mineral elements, and generally low level of toxicants. Furthermore, the antioxidant contents of the five TLVs highlighted their biological values as medicinal plants with the high potency in fighting diseases. The above results showed that these vegetables could be valuable and important contributors to the diets of the rural poor and semi-urban people of southeast Nigeria for improved human nutrition, reduction of hidden hunger and food security.

\section{Keywords}

Nutrient Improvement, Underutilized Leafy Vegetables, Micronutrient, Food Security, Southeast Nigeria

\footnotetext{
${ }^{*}$ Corresponding author.
}

How to cite this paper: Nnamani, C.V., Oselebe, H.O. and Igboabuchi, A.N. (2015) Bio-Banking on Neglected and Underutilized Plant Genetic Resources of Nigeria: Potential for Nutrient and Food Security. American Journal of Plant Sciences, 6, 518-523. http://dx.doi.org/10.4236/ajps.2015.64056 


\section{Introduction}

Nigeria is a country that is richly blessed with abundant natural and human resources. However, the country experiences persistent food crisis both in terms of quantity and quality. Cases of malnutrition and under nutrition have been recorded and the food intake requirements for most Nigerians are below the international standard [1]. Food insecurity exists when there is "limited or uncertain availability of nutritionally adequate and safe foods or limited or uncertain ability to acquire acceptable foods in socially acceptable ways” [2]. Previous reports [3] indicated that an estimated 842 million people were suffering from chronic hunger world over in 2011-2013.

Globally, food security is dependent on a handful of crops. It was reported [4] that food insecurity in relation to hidden hunger in Sub-Saharan Africa was due to the high proportion of people who could not meet their daily protein needs. This is largely because a significant number of people, especially Nigerians, have progressively become dependent on a handful of carbohydrate based staples like yam, maize, and rice. In Nigeria, over $50 \%$ of the body's requirements for proteins, calories and minerals are met by these few starchy staples. This narrowing base of food security limits the sources of nutrients and livelihood options for these poor rural and peri-urban communities, particularly in marginal areas, thereby snowballing malnutrition/hidden hunger [5].

The chronic yoke of malnutrition in Nigeria cannot be solved by food aid or food trade from developed countries, but rather by the adequate and sustainable utilisation of the rich biodiversity in the country [5]. This is more crucial now given the looming food crisis that threatens to further reduce the inadequate food security experienced in many states of Nigeria. Micronutrient deficiencies are estimated to affect at least 2 billion people who suffer from hidden hunger [6]. Since micronutrient deficiencies lead to a vast range of diseases and other health disorders, their decrease is likely to help the achievement of some of the health-related MDGs and reduction in child and maternal mortality and other none communicable diseases.

Diversification of crops and consumption habits to include underutilized traditional leafy vegetables is the most sustainable way of reducing and controlling the hydra headed effects of micronutrient deficiencies in resource-poor communities of southeast Nigeria. This is because, underutilized plant genetic resources can make substantial contribution in meeting the nutritional needs of the population, especially the low income group, during times of food seasonal scarcity [7].

These crops are cheap, resilience to climate change and readily affordable to many. Being accessible to lowincome communities, they play a crucial role in improving their food security, nutritional status and livelihood options [8]. The main objectives of this work were to 1) assess the nutritional values of five TLVs; 2) determine the level of their antioxidant content; and 3) evaluate their photochemical content. This will create more awareness on their nutritional values and enhance their selection as component of the cooked food in dietary menu of the rural and semi-rural people of southeast Nigeria.

\section{Materials and Methods}

\subsection{Sample Collection}

Freshly harvested leaves of Abelmoschus esculentus (Okra/okro), Agaratum conyzoides (Goat weed) Acanthus montanus (Leopard's tongue), Bombax buonopozense (Kapok) and Mucuna flagellipes (Devils bean) were collected from some local communities in southeast Nigeria. The leafy parts of these vegetables were washed, cut and oven dried at $90^{\circ} \mathrm{C}$ for 6 hours. The dried leaves were pulverized, packaged in airtight sterile bottles, labelled and stored in a refrigerator ready for use.

\subsection{Proximate Analysis}

The chemical analysis of percentage moisture, crude fibre, protein, ash, fat and carbohydrate were determined using methods described by Pearson [9]. The crude protein was obtained by determining the organic nitrogen content of the sample using micro-Kjeldah method and multiplying the nitrogen by a protein conversion unit of 6.25. The ash content of the leaves was estimated by igniting the weighed sample in the weighing crucible at a temperature of $500^{\circ} \mathrm{C}$ for about 3 hours in a muffle furnace, while the moisture content was determined using oven method. The crude fibre and fat determination were done by hydrolysing the samples with $0.128 \mathrm{ml}$ of $\mathrm{H}_{2} \mathrm{SO}_{4}$ and $0.223 \mathrm{ml}$ of $\mathrm{KOH}$ and Soxhlet extraction method, respectively. The carbohydrate content was determined by their difference while the antioxidant values were determined using spectrophotometer methods as described [9]. 


\subsection{Physiochemical Analysis}

The mineral contents were determined using dry ashing procedure as described by Association of Agricultural Chemists [10]. About $2 \mathrm{~g}$ of each sample was pre-ashed in a crucible for 1 - 2 hours until the sample is completely charred on a hot plate. The pre-ashed sample was then placed on a muffle furnace and ashed at $500^{\circ} \mathrm{C}$ for about 3 hours or until the ash is white. After ashing, the sample was cooled and weighed. This was transferred into a $50 \mathrm{ml}$ volumetric flask by carefully washing the crucible with $5 \mathrm{ml}$ of $30 \% \mathrm{HCl}$. The solution was diluted to volume with iodized water and was then used for individual mineral (vitamin A, C and E, Lead and zinc) determination using Spectrophotometer and flame photometer. Three replications were made for each of the sample to analyse for their proximate composition and mineral contents to evaluate their nutritive values in human food.

\subsection{Statistical Analysis}

Data were analysed using a number of statistical techniques, specifically percentages, charts, means and standard deviations.

\section{Results and Discussion}

\subsection{Proximate Composition}

The results of the physiochemical analysis of the five TLVs of southeast Nigeria is presented in Table 1. Result showed that the plants are potentially endowed with essential nutrients required for the maintenance of good human health and could be utilized as adaptive technologies for food security in a changing climate. The moisture content was highest in Ageratum conyzoides (83.20 \pm 0.02 ) and lowest in Mucuna flagellipes. These results are in line with other works that reported high moisture content and noted that it helps in maintaining the protoplasmic stability of the cells, although it could also make them perishable and susceptible to spoilage by microorganism during storage [8] [11].

The protein value was highest in Mucuna flagellipes $(2.59 \pm 0.02)$ and least in Acanthus mantanus $(0.99 \pm$ 0.02). These amount of protein (when converted) of the total nitrogen in a leafy vegetable were variable for these leafy vegetables analysed in the present study. They may not compare favourably with the dry milled percentage values reported for leafy vegetables like Brachystegia eurycoma and Tamaradus indica which was 5.78\% [12]. However, they were higher than the dry milled percentage values for leafy vegetables like Celosia argentea (0.7\%), fluted pumpkin (1.8\%) and Gnetum africanum (1.2\%) [13].

The ash content, which is a measure of the mineral content of food, had values ranging from $1.75 \pm 0.02$ $3.50 \pm 0.20$ (Table 1). This result is in line with the results [12] reported an ash content of some traditional leafy vegetables that ranged from $0.6 \%-34 \%$.

Furthermore, the low content of fat in all the TLVs is an indication that they are good dietary menu for persons in search of weight reducing meals and diabetic patients. The fiber content of the vegetables analysed was low. However, these components have little food value, although it provides the bulk necessary for proper peristaltic action in the intestinal tract [14]. Vegetables are good sources of fiber, which lowers the body cholesterol level, consequently decreases the risk of cardiovascular diseases. It is required that vegetables should be used frequently as they are good for heath and provides all the essential nutrients for normal body functions when consumed in appropriate combination.

Table 1. Nutritional values of five underutilized vegetables of southeast Nigeria.

\begin{tabular}{ccccccc} 
Species & Moisture & Protein & Ash & Fiber & Fat & \\
\hline Abelmoschus esculentus & $80.85 \pm 0.2$ & $1.60 \pm 0.20$ & $2.45 \pm 0.02$ & $1.44 \pm 0.02$ & $0.40 \pm 0.20$ & $13.26 \pm 0.02$ \\
Ageratum conyzoides & $83.20 \pm 0.02$ & $1.02 \pm 0.2$ & $2.90 \pm 0.02$ & $2.30 \pm 0.20$ & $0.80 \pm 0.20$ & $12.15 \pm 0.0 .61$ \\
Acanthus montanus & $82.80 \pm 0.02$ & $0.99 \pm 0.02$ & $2.70 \pm 0.20$ & $1.89 \pm 0.02$ & $0.50 \pm 0.20$ \\
Bombax buonopozense & $70.85 \pm 0.02$ & $2.30 \pm 0.02$ & $3.50 \pm 0.20$ & $2.90 \pm 0.20$ & $0.70 \pm 0.20$ & $11.12 \pm 0.02$ \\
Mucuna flagellipes & $69.35 \pm 0.02$ & $2.59 \pm 0.02$ & $1.75 \pm 0.02$ & $2.00 \pm 0.20$ & $0.30 \pm 0.20$ & $24.01 \pm 0.02$ \\
\hline
\end{tabular}




\subsection{Physiochemical Composition}

Furthermore, the antioxidant contents of the five TLVs lend credence to the biological values of the vegetables as medicinal plants with high potency in fighting diseases. This is in line with previous results [15] which noted that vegetables are sources of essential bioactive compounds which are good in fighting many heart related diseases.

Vitamin A (Figure 1) was highest in M. flagellipes (695.40 $\pm 0.02 \mathrm{Iu}$ ), followed by M. montanus (340.43 \pm $0.02 \mathrm{Iu}$ ), while the highest value for Vitamin $\mathrm{C}$ was recorded from A. conyzoides (12.65 $\pm 0.02 \%$; Figure 2). Vitamin $\mathrm{C}$ aids in wound healing, is essential for healthy bone, helps the body to absorb calcium and iron and contributes in brain functioning (Carpenter et al., 2009). The vitamin E content of these plants ranges from 4.40 $\pm 0.20 \mathrm{mg} / 100 \mathrm{~g}$ in A. montanus and $19.60 \pm 0.20 \mathrm{mg} / 100 \mathrm{~g}$ in B. buonopozense (Figure 3). This result showed

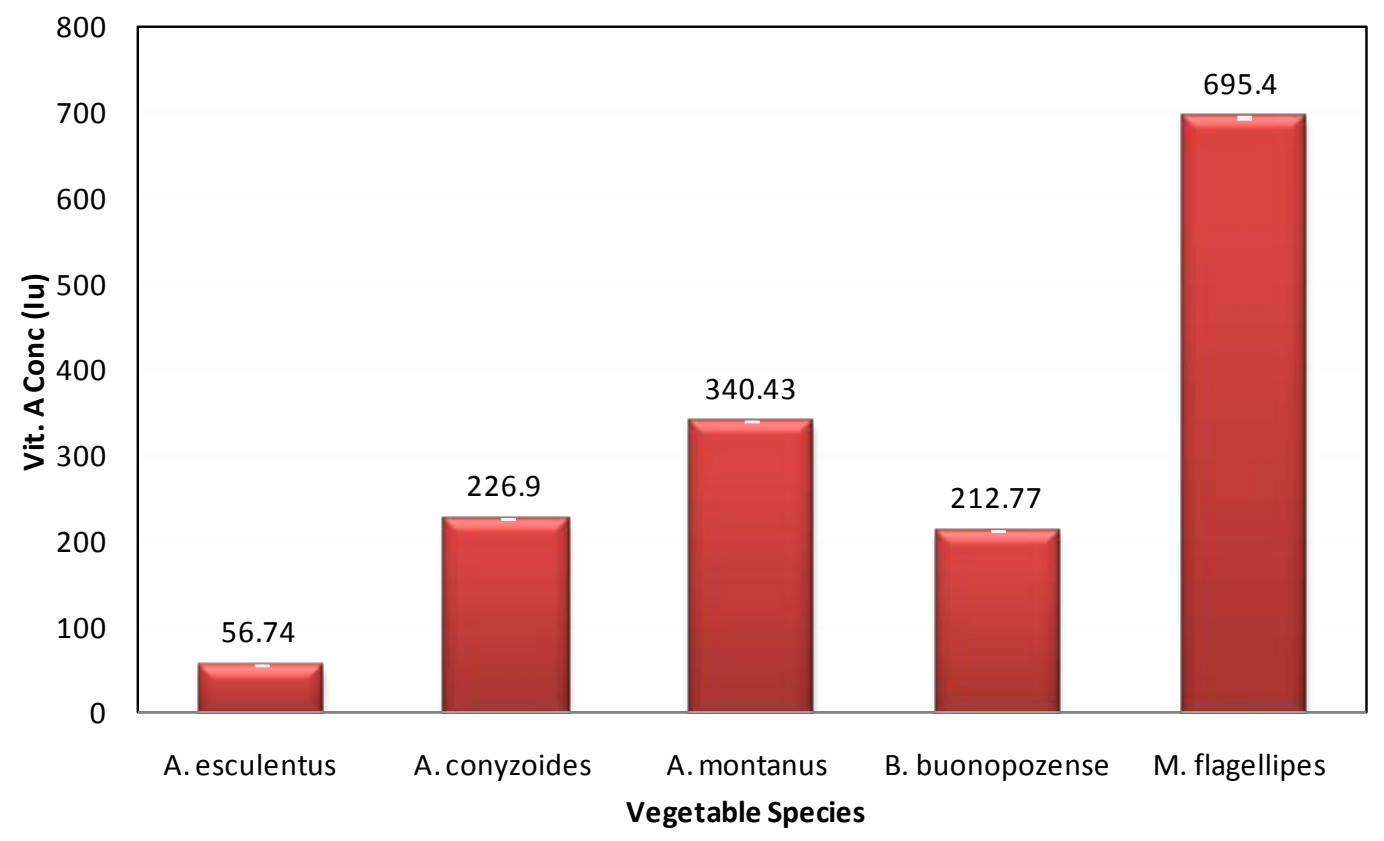

Figure 1. Vitamin A contents of five traditional leafy vegetables of southeast Nigeria.

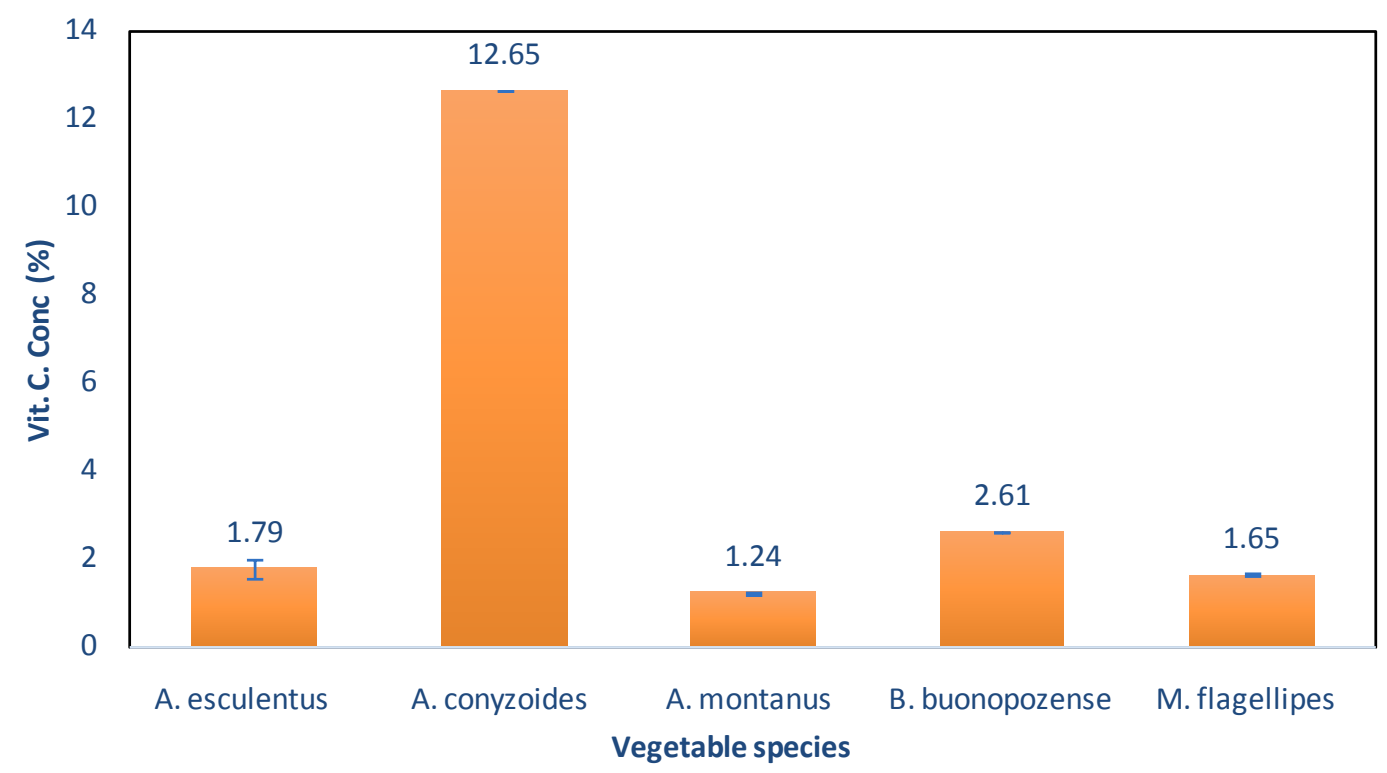

Figure 2. Vitamin C content of five traditional leafy vegetables of southeast Nigeria. 


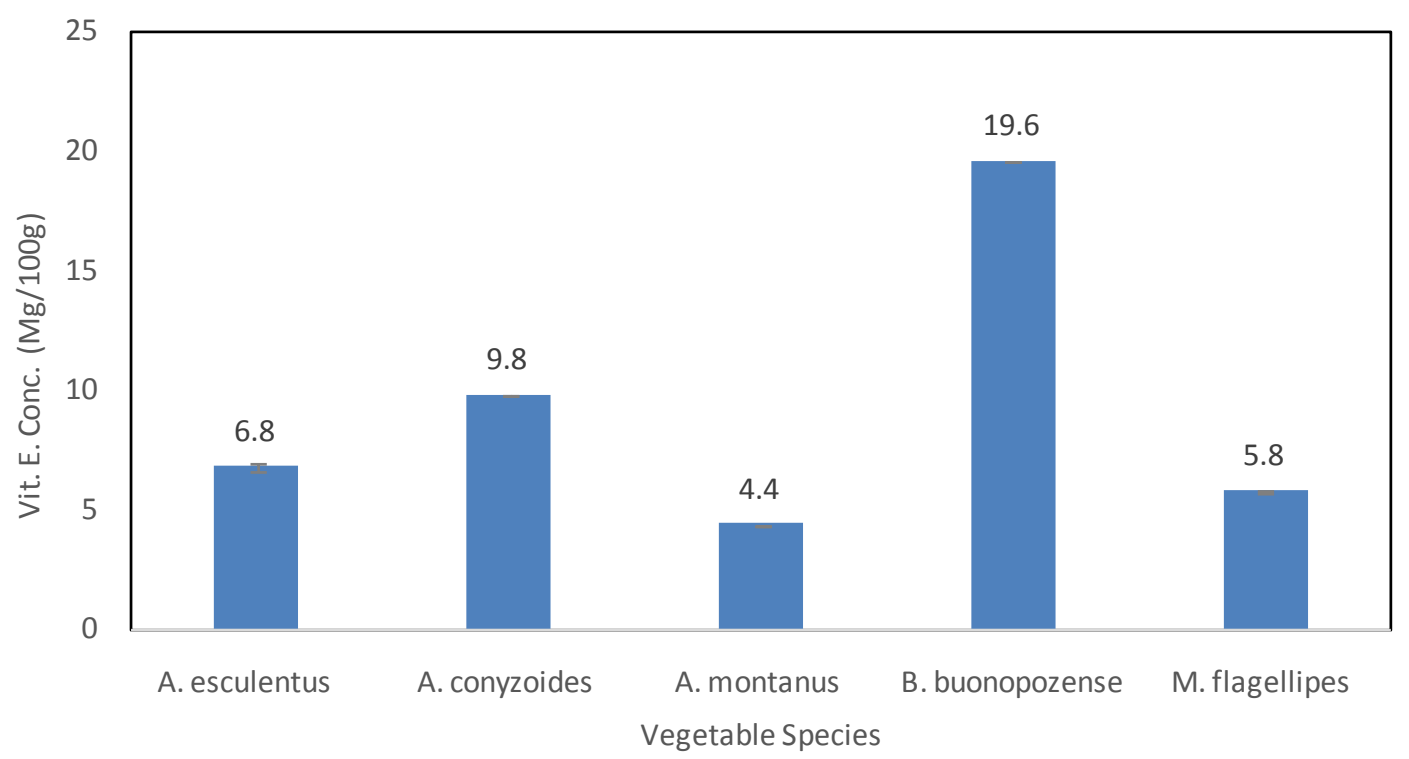

Figure 3. Vitamin E contents of five traditional leafy vegetables of southeast Nigeria.

that these plants nourishes the skin and promote healthy skin. These TLVs are important contributors to the diets of the rural populace in southeast Nigeria for improved nutrition, combating hidden hunger and food security.

The zinc content of the TVLs ranges from $144.19 \pm 0.02$ to $223.26 \pm 0.02 \mathrm{ppm}$ in the studied species, which is appreciably high when compared with the daily recommended quantity of 7 milligrams average for adult woman and an average of 9.5 milligrams daily for male. The risk for women to have a zinc deficiency is much greater than a man, especially if they are malnourished because of an eating disorder or when they are breastfeeding.

Lead was absent in all the TLVs studied. The complete absence of Lead in these plant genetic resources makes them fit for human consumption. This is in line with another result [16] that the presence of Lead in human system is devastating and dangerous because it inhibits oxygen and calcium transport resulting to the alteration nerve transmission in the brain. They further noted that Lead builds up in soft tissue such as the kidneys, bone marrow, liver, and brain—as well as bones and teeth.

\section{Conclusions}

The projection of Sub Saharan Africa for the next two decades, particularly as regards life expectancy and food security is bleak and challenging. Practical intervention in nutrition and consumption habit through diversifications to include underutilized crops is highly critical and needed. Nutritional characterization of these underutilized traditional leafy vegetables is an innovative stride and their inculcation in the diet habits of these resource poor communities could potentially address some of those indicators of malnutrition prevalent in these areas. At the same time, the income generating potentials of the identified traditional vegetables is essential in alleviating the poverty level of these rural farm families especially women on whose shoulders the responsibilities of caring for the family rests upon.

Conclusively, the results of this study showed that the leaves of Bombax buonopozense and Abelmoschusesculentus contained appreciable amount of proteins, fat, fibre, carbohydrate and mineral elements, and generally low level of toxicants. Thus, it can be concluded that leaves of these species can contribute significantly to the nutrient requirements of man and should be used as a source of nutrients to supplement other major sources.

\section{References}

[1] Otaha, I.J. (2013) Food Insecurity in Nigeria: Way Forward. African Research Review, 7, 26-35.

[2] Bickel, G., Nord, M., Price, C., Hamilton, W.L. and Cook, J.T. (2000) Guide to Measuring Household Food Security, Revised 2000. USDA, Food and Nutrition Service. www.fns.usda.gov/sites/default/files/FSGuide_0.pdf

[3] FAO, IFAD and WFP (2013) The State of Food Insecurity in the World 2013. The Multiple Dimensions of Food Security. Rome, FAO. 
[4] von Grebmer, K., Ruel, M.T., Menon, P., Nestorova, B., Olofinbiyi, T., Fritschel, H., Yohannes, Y., von Oppeln, C., Towey, O., Golden, K. and Thompson, J. (2010) 2010 Global Hunger Index: The Challenge of Hunger: Focus on the Crisis of Child Undernutrition. Bonn, Washington DC, and Dublin: Deutsche Welthungerhilfe, International Food Policy Research Institute, and Concern Worldwide.

[5] Nnamani, C.V. (2014) Nourishing the Malnourished, United Nations University, Institute for Natural Resources in Africa (UNU-INRA). Policy Brief, 2, 1-4.

[6] Burchi, F., Fanzo, J. and Frison, E. (2011) The Role of Food and Nutrition System Approaches in Tackling Hidden Hunger. International Journal of Environmental Research and Public Health, 8, 358-373. http://dx.doi.org/10.3390/ijerph8020358

[7] Okeke, E.C., Eneobong, H.N., Uzuegbunam, A.O., Ozioko, A.O. and Kuhnlein, H. (2008) Igbo Traditional Food System: Documentation, Uses and Research Needs. Pakistan Journal of Nutrition, 7, 365-376. http://dx.doi.org/10.3923/pjn.2008.365.376

[8] Nnamani, C.V., Oselebe, H.O. and Agbatutu, A. (2009) Assessment of Nutritional Values of Three Underutilized Indigenous Leafy Vegetables of Ebonyi State, Nigeria. African Journal of Biotechnology, 8, 2321-2324.

[9] Pearson, D. (1976) The Chemical Analysis of Food. Churchill and Livingstone, London.

[10] Association of Official Analytical Chemist (AOAC) (1990) Official Methods of Analysis. 15th Edition, Washington DC, 123.

[11] George, P.M. (2003) Encyclopedia of Foods. Vol. 1, Humane Press, Washington DC, 526.

[12] Ajayi, I.A., Oderinde, R.A., Kalogbola, D.O. and Ukponi, J.U. (2006) Oil of Underutilized Legumes from Nigeria. Food Chemistry, 99, 115-120. http://dx.doi.org/10.1016/j.foodchem.2005.06.045

[13] Okafor, J.C. (1995) Conservation and Use of Traditional Vegetables from Woody Forest Species in South-Eastern Nigeria. Proceedings of the IPGRI Workshop on Genetic Resources of Traditional Vegetables in Africa, Nairobi, 29-31 August 1995.

[14] Levetin, K. and McMahon, M. (2003) Plants and Society. 3rd Edition, McGraw-Hill Publishing Company, New York.

[15] Mozaffarian, D., Katan, M.B., Ascherio, A., Stampfer, M.J. and Willet, W.C. (2006) Trans Fatty Acids and Cardiovascular Disease. New England Journal of Medicine, 354, 1601-1613. http://dx.doi.org/10.1056/NEJMra054035

[16] Natural Resources Defence Council, NRDC (2014) How Lead Poisons the Human Body. www.nrdc.org 